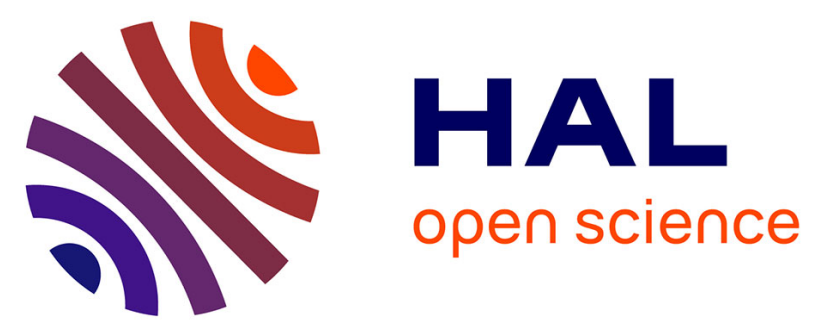

\title{
Matrix metalloproteinase gene polymorphisms and bronchopulmonary dysplasia: identification of MMP16 as a new player in lung development.
}

\author{
Alice Hadchouel, Fabrice Decobert, Marie-Laure Franco-Montoya, Isabelle
} Halphen, Pierre-Henri Jarreau, Olivier Boucherat, Emmanuel Martin, Alexandra Benachi, Serge Amselem, Jacques R. Bourbon, et al.

\section{To cite this version:}

Alice Hadchouel, Fabrice Decobert, Marie-Laure Franco-Montoya, Isabelle Halphen, Pierre-Henri Jarreau, et al.. Matrix metalloproteinase gene polymorphisms and bronchopulmonary dysplasia: identification of MMP16 as a new player in lung development.. PLoS ONE, 2008, 3 (9), pp.e3188. 10.1371/journal.pone.0003188 . inserm-00447737

\section{HAL Id: inserm-00447737 https://www.hal.inserm.fr/inserm-00447737}

Submitted on 15 Jan 2010

HAL is a multi-disciplinary open access archive for the deposit and dissemination of scientific research documents, whether they are published or not. The documents may come from teaching and research institutions in France or abroad, or from public or private research centers.
L'archive ouverte pluridisciplinaire HAL, est destinée au dépôt et à la diffusion de documents scientifiques de niveau recherche, publiés ou non, émanant des établissements d'enseignement et de recherche français ou étrangers, des laboratoires publics ou privés. 


\title{
Matrix Metalloproteinase Gene Polymorphisms and Bronchopulmonary Dysplasia: Identification of MMP16 as a New Player in Lung Development
}

\author{
Alice Hadchouel ${ }^{1,2}$, Fabrice Decobert ${ }^{1,2,3}$, Marie-Laure Franco-Montoya ${ }^{1,2}$, Isabelle Halphen ${ }^{1,2}$, Pierre- \\ Henri Jarreau ${ }^{2,4,10}$, Olivier Boucherat ${ }^{1,2}$, Emmanuel Martin ${ }^{5}$, Alexandra Benachi ${ }^{1,2,6}$, Serge Amselem ${ }^{7}$, \\ Jacques Bourbon ${ }^{1,2}$, Claude Danan ${ }^{1,2,3,8}$, Christophe Delacourt ${ }^{1,2,9 *}$ \\ 1 INSERM, Unité 841, IMRB, équipe 06, Créteil, France, 2 PremUp, Paris, France, 3 Réanimation Néonatale, Centre Hospitalier Intercommunal, Créteil, France, 4 Service de \\ médecine néonatale de Port-Royal, AP-HP, Hôpital Cochin, Paris, France, 5 IntegraGen, Evry, France, $\mathbf{6}$ Service d'Obstétrique et Gynécologie, AP-HP, Hôpital Necker, Paris, \\ France, 7 INSERM U654, GH Armand Trousseau, Paris, France, 8 Unité Fonctionnelle de Recherche Clinique, Centre Hospitalier Intercommunal, Créteil, France, 9 Université \\ Paris 12, Faculté de Médecine, IFR10, Créteil, France, 10 Université Paris Descartes, Faculté de Médecine, Paris, France
}

\begin{abstract}
Backgound: Alveolarization requires coordinated extracellular matrix remodeling, a process in which matrix metalloproteinases (MMPs) play an important role. We postulated that polymorphisms in MMP genes might affect MMP function in preterm lungs and thus influence the risk of bronchopulmonary dysplasia (BPD).

Methods and Findings: Two hundred and eighty-four consecutive neonates with a gestational age of $<28$ weeks were included in this prospective study. Forty-five neonates developed BPD. Nine single-nucleotide polymorphisms (SNPs) were sought in the MMP2, MMP14 and MMP16 genes. After adjustment for birth weight and ethnic origin, the TT genotype of MMP16 C/T (rs2664352) and the GG genotype of MMP16 A/G (rs2664349) were found to protect from BPD. These genotypes were also associated with a smaller active fraction of MMP2 and with a 3-fold-lower MMP16 protein level in tracheal aspirates collected within 3 days after birth. Further evaluation of MMP16 expression during the course of normal human and rat lung development showed relatively low expression during the canalicular and saccular stages and a clear increase in both mRNA and protein levels during the alveolar stage. In two newborn rat models of arrested alveolarization the lung MMP16 mRNA level was less than $50 \%$ of normal.
\end{abstract}

Conclusions: MMP16 may be involved in the development of lung alveoli. MMP16 polymorphisms appear to influence not only the pulmonary expression and function of MMP16 but also the risk of BPD in premature infants.

Citation: Hadchouel A, Decobert F, Franco-Montoya M-L, Halphen I, Jarreau P-H, et al. (2008) Matrix Metalloproteinase Gene Polymorphisms and Bronchopulmonary Dysplasia: Identification of MMP16 as a New Player in Lung Development. PLoS ONE 3(9): e3188. doi:10.1371/journal.pone.0003188

Editor: Rory Edward Morty, University of Giessen Lung Center, Germany

Received May 9, 2008; Accepted August 21, 2008; Published September 11, 2008

Copyright: (C) 2008 Hadchouel et al. This is an open-access article distributed under the terms of the Creative Commons Attribution License, which permits unrestricted use, distribution, and reproduction in any medium, provided the original author and source are credited.

Funding: INSERM Programme Hospitalier de Recherche Clinique AOR03 - Assistance Publique - Hôpitaux de Paris. AH was founded by a grant from Association des Juniors en Pédiatrie.

Competing Interests: The authors have declared that no competing interests exist.

* E-mail: christophe.delacourt@chicreteil.fr

\section{Introduction}

Despite major advances in the care of very-low-birth-weight (VLBW) infants, bronchopulmonary dysplasia (BPD) still affects 20 to $40 \%$ of survivors [1]. BPD appears to result from arrested lung development and is characterized by abnormal alveolar septation and abnormal microvascular maturation [2]. Alveolarization requires coordination of extracellular matrix remodeling with epithelial morphogenesis and capillary growth [3]. This process involves matrix metalloproteinases (MMPs), which are classified into two major groups according to their subcellular localization: membrane-type MMPs (MT-MMPs) and secreted MMPs. Among secreted MMPs, MMP2 is known to play a key role in lung development and repair after injury. Mice lacking this proteinase show delayed alveolar development [4], and low MMP2 levels in tracheal effluent and plasma have been linked to an increased risk of BPD in infants [5,6]. Type I transmembrane MT-MMPs participate in the activation of the zymogen form of MMP2 (proMMP2). Among these, MT1-MMP (MMP14) has a major role in alveolarization. We recently observed a fourfold increase in MMP14 transcripts in lung fibroblasts during alveolarization [7], while mice lacking this enzyme have a reduced alveolar surface area and enlarged air spaces $[8,9]$, although this seems partly independent of the ability of MMP14 to activate MMP2 [9]. MT3-MMP (MMP16) was originally cloned from a human placental cDNA library [10]. Although its role in lung development has not previously been studied, its ability to localize on the cell membrane and to activate pro-MMP2 has been clearly demonstrated. MMP16 is also known to have a splice variant, consisting of a soluble form lacking the transmembrane domain. This soluble form can also activate pro-MMP2 [11].

Although exposure of the immature lung to various insults is thought to play a central role in the onset of BPD, significant genetic susceptibility to BPD was recently demonstrated in 
preterm infants [12]. Hereditary differences in the expression of genes critical for lung development may therefore have a role in BPD pathogenesis. We postulated that polymorphisms in MMP genes might affect MMP function in preterm lung and thereby influence the risk of BPD at a given gestational age. Indeed, a single-nucleotide polymorphism (SNP) in the promoter of the MMP2 gene $(-1306 \mathrm{C} / \mathrm{T})$ modulates the promoter activity of MMP2 and has functional significance [13]. In addition, a haplotype of four MMP14 polymorphisms $(-130 \mathrm{~T}$ : +256 T: +6762 C: $+7131 \mathrm{C}$ ) has been linked to chronic obstructive pulmonary disease [14]. Finally, the MMP16 splice variant might potentially be generated by polymorphism of the gene region coding for the hemopexin domain [11].

Our initial aim in this study was to examine whether any of nine SNPs in the MMP2, MMP14, and MMP16 genes was associated with BPD in premature infants, and with the level of MMP2 activity in tracheal effluents. As we found a significant association with two SNPs in the MMP16 gene, we further examined the expression of this enzyme during normal human and rat lung development, and in newborn rat models of arrested alveolar development.

\section{Methods}

\section{Study population}

Two hundred and eighty-four neonates with a gestational age of $<28$ weeks were included from two neonatal intensive care units (Creteil and Cochin-Port Royal) between March 2002 and December 2006. All were inborn, and received prophylactic surfactant treatment immediately after birth, in the delivery room. The mean term was 26.4 \pm 0.1 (SE) weeks (range 23.6-27.9 weeks), and the mean birth weight was $838 \pm 11 \mathrm{~g}(440-1410 \mathrm{~g})$. Perinatal factors susceptible to influence the risk for BPD were collected: bacteriologically proven maternofetal infection ; antenatal steroid therapy ; histologically defined chorioamnionitis ; persistent ductus arteriosus requiring medical or surgical treatment ; bacteriologically proven postnatal sepsis ; air leaks. The duration of ventilation support was not analyzed because of evolving strategies over study time. The diagnosis of BPD was based on the continued need for oxygen supplementation at a postmenstrual age (PMA) of 36 weeks, according to the standardized physiologic test validated by Walsh [15]. The study was approved by the local ethics committee (CCPPRB Henri Mondor), and written informed consent was obtained from the parents.

\section{Collection of tracheal secretions}

A tracheal aspirate was obtained from 148 of the neonates immediately after birth (Day 0), before surfactant instillation. One hundred and five neonates were resampled before extubation, or on Day 3 when still intubated (mean: $2.5 \pm 0.1$ postnatal days). Tracheal aspiration and sample preparation were performed as previously described [5,16]. Briefly, suction was performed with a small catheter and was preceded by instillation of $0.2 \mathrm{ml}$ of isotonic saline. The aspirate was collected in an infant mucus extractor (Vygon, Ecouen, France), then diluted in $0.2 \mathrm{ml}$ of isotonic saline, gently vortexed, and centrifuged at $1200 \mathrm{rpm}$ for $10 \mathrm{~min}$ at $4^{\circ} \mathrm{C}$. The supernatant was recovered and stored at $-80^{\circ} \mathrm{C}$. The dilution factor induced by this technique is low $[5,16]$, allowing the results to be expressed per milliliter of supernatant.

\section{Human fetal lung tissue sampling}

Lung tissue samples were obtained at autopsy after medical termination of pregnancy or neonatal death, with the parents written informed consent. The terminations complied with French legislation, and the study was approved by our institutional ethics committee. The fetuses were free of pulmonary diseases and the samples were histologically normal, with no hypoplasia. Detailed clinical data on the lung tissue donors have been reported elsewhere [17]. Fetal age (postconception) is used throughout the paper. The lung tissues were homogenized in RIPA buffer containing protease inhibitors (Roche Diagnostics, http://wrew.roche.com).

\section{Animal models and rat lung tissue}

Dated pregnant Sprague-Dawley rats were purchased from Charles River (Saint Germain sur l'Arbresle, France). The day of mating was designated day 0 of gestation. Term is 22 days. Lung tissues were collected between fetal day 18 and postnatal day 21 . Lung tissue from adult rats (8 weeks of age) were also collected. Fetuses were retrieved by cesarean section under pentobarbital anesthesia. Lungs from fetuses and pups were immediately frozen in liquid nitrogen and kept at $-80^{\circ} \mathrm{C}$ until RNA extraction or immunoblot analysis. Animal experiments complied with the Guide for Care and Use of Laboratory Animals, and were authorized by the French Ministry of Agriculture.

\section{In vivo treatment of rat pups}

We used two treatments known to induce alveolar growth disorders in newborn rats, namely hyperoxia and dexamethasone. We have previously reported resulting morphometric alterations [18].

Hyperoxia. Rat pups and their dams were placed in Plexiglas exposure chambers (Charles River) and run in parallel with either $>95 \%$ or $21 \%$ (room air) $\mathrm{FiO}_{2}$ from day 0 to day 7 . The oxygen concentration was regularly monitored. Because adult rats have limited resistance to high $\mathrm{O}_{2}$, the dams were switched daily between $\mathrm{O}_{2}$-exposed and room air-exposed litters. Pups from two different litters were mixed so that there were littermates in both conditions. The chambers were opened for $20 \mathrm{~min}$ every day to switch dams between the air and $\mathrm{O}_{2}$ environments and to clean the cages. On day 7, the pups were killed by intraperitoneal sodium pentobarbital injection $(70 \mathrm{mg} / \mathrm{kg}$, Ceva, Libourne, France), and exsanguinated by aortic transsection. The lungs were immediately placed in liquid nitrogen and kept at $-80^{\circ} \mathrm{C}$ until RNA or protein extraction.

Dexamethasone (Dex) treatment. Two different litters were subdivided into three groups of animals, that received an intraperitoneal injection of 0.1 or $0.5 \mu \mathrm{g} / \mathrm{g} /$ day water-soluble Dex (Sigma, L'Isle d'Abeau, France), or the vehicle alone (saline, control group), from birth to day 5. Five animals were used for each experimental condition. The pups were killed on day 6 as described above.

\section{MMP2 measurements in tracheal aspirates}

A selective ELISA system (R\&D Systems, Abingdon, UK) was used to determine total MMP2 concentrations in tracheal aspirate supernatants, according to the manufacturer's instructions. MMP2 activity was evaluated by zymography, as previously described [5]. Supernatants of tracheal aspirates were analyzed by electrophoresis in $8 \%$ (wt/vol) polyacrylamide gels containing $1 \mathrm{mg} / \mathrm{ml}$ gelatin in the presence of SDS in nonreducing conditions. After electrophoresis, the gels were washed in $2.5 \%$ Triton X-100 for $1 \mathrm{~h}$ and then rinsed briefly and incubated at $37^{\circ} \mathrm{C}$ for $24 \mathrm{~h}$ in buffer containing $100 \mathrm{mM}$ Tris- $\mathrm{HCl}, \mathrm{pH} \mathrm{7.40,}$, and $10 \mathrm{mM}$ $\mathrm{CaCl}$ 2. The gels were then stained with Coomassie brillant blue R250 and restained in a solution of 7.5\% acetic acid and 5\% methanol. Enzyme activities in the gel slabs were quantified by means of image analysis (NIH Image software 1.52 for Macintosh), on the basis of both the surface area and the intensity of lysis bands. Results were expressed as arbitrary units (AU) per $24 \mathrm{~h}$ per microliter of supernatant. The total MMP2 level was calculated as the sum of activities measured at $72 \mathrm{kDa}$ (proenzyme) and $68 \mathrm{kDa}$ 
(activated enzyme). The fraction of activated gelatinase was calculated as the activated/total enzyme ratio.

\section{Immunoblot analysis}

Immunoblot analysis was applied to supernatants of tracheal aspirates and to human and rat lung tissue homogenates. Protein content was assayed in each sample with the Bradford assay. A fixed amount of total protein $(12 \mu \mathrm{g}, 80 \mu \mathrm{g}$, and $50 \mu \mathrm{g}$ for tracheal aspirates, human lung tissue, and rat lung tissue, respectively) was electrophoresed on 8 to $10 \%$ SDS-polyacrylamide gels then transferred to polyvinylidene-fluoride membranes (Millipore, SaintQuentin en Yvelines, France), then stained with Ponceau $\mathrm{S}$ dye (Sigma, http://www.sigmaaldrich.com). After blocking with 5\% nonfat dry milk in Tris-buffer saline containing $0.1 \%$ Tween-20 (TTBS) at room temperature for $90 \mathrm{~min}$, the membranes were exposed to a rabbit polyclonal antibody against MMP16 (Abcam, Cambridge, UK), diluted 1:1000 in 2\% non fat dry milk in TTBS at room temperature for $2 \mathrm{~h}$. After five rinses in TTBS, the membranes were incubated for $1 \mathrm{~h}$ with a secondary peroxidase-conjugated IgG antibody (Dako, Trappes, France) diluted 1:2500. The membranes were then incubated for $1 \mathrm{~min}$ in chemiluminescent detection reagent (ECL, GE Healthcare Life Sciences, Velizy, France) before exposure to KODAK BioMax MS film for $15 \mathrm{~min}$. NIH image software was used for densitometric analysis of the blots.

\section{Genotyping}

Genomic DNA was extracted from cord-blood leukocytes by using the Nucleon kit (Amersham). The SNPs studied here are summarized Table 1. SNPs in the MMP2 and MMP14 genes that had previously been linked to respiratory diseases were included in this study, namely $-1306 \mathrm{C} / \mathrm{T}$ in the MMP2 gene $[19,20]$, and $-129 \mathrm{G} / \mathrm{T},+256 \mathrm{~T} / \mathrm{C}$, +6762 C/G, and +7131 T/C in the MMP14 gene [14]. +6802 G/A and $+6926 \mathrm{C} / \mathrm{T}$ SNPs were also included, based on their exonic location. Two "tag" SNPs (rs2664349 and rs2664352) that determine a haplotype in the region of the MMP16 gene encoding the hemopexin domain were selected from HapMap data.

The $-1306 \mathrm{C} / \mathrm{T}$ genotype was determined by polymerase chain reaction amplification (PCR) followed by restriction fragment length

Table 1. Single-nucleotide polymorphisms (SNPs) studied in the MMP2, MMP14, and MMP16 genes.

\begin{tabular}{lllll}
\hline Gene & Genomic location & Reference & Alleles & Fluorophores* \\
\hline MMP2 & -1306 & $r s 243865$ & C/T & - \\
MMP14 & -129 & $r s 1003349$ & G/T & G: VIC \\
& & & & T: FAM \\
MMP14 & +256 & $r s 1042703$ & T/C & T: FAM \\
& & & & C: VIC \\
MMP14 & +6762 & $r s 2236302$ & C/G & - \\
MMP14 & +6802 & $r s 1042704$ & G/A & - \\
MMP14 & +6926 & $r s 2236303$ & C/T & - \\
MMP14 & +7131 & $r s 2236307$ & T/C & - \\
MMP16 & +39811 & $r s 2664349$ & A/G & A: VIC \\
& & & & G: FAM \\
MMP16 & +43827 & $r s 2664352$ & C/T & C: VIC \\
& & & & T: FAM \\
\hline
\end{tabular}

${ }^{*}$ Allele-specific fluorogenic probes used for genotyping with the TaqMan ${ }^{\circledR}$ technique.

doi:10.1371/journal.pone.0003188.t001 polymorphism analysis (RFLP). The forward and reverse primers were designed with Primer Express software (Applied Biosystems), as follows: 5'-CTT CGT AGG CTG GTC CTT ACT GA-3' and 5'GTG AGA GCT GAA GAG CTA AAG AGC T-3'. The penultimate nucleotide of the reverse primer was modified $(\mathrm{G}$ replaced by $\mathbf{C}$ ) in order to create a restriction site for Bfal. PCR was carried out in a $50-\mu \mathrm{L}$ volume containing $200 \mathrm{ng}$ of genomic DNA, $5 \mu \mathrm{L}$ of $10 \times$ PCR Rxn Buffer (Invitrogen), $2 \mu \mathrm{L}$ of $50 \mathrm{mM} \mathrm{MgCl}_{2}$ (Invitrogen), $1 \mu \mathrm{L}$ of nucleotide mix (dNTP $10 \mathrm{mM}$, Invitrogen), 13 pmol of forward and reverse primer and 1.5 units of Taq polymerase (Recombinant Taq DNA Polymerase, Invitrogen). The thermal cycling conditions were $94^{\circ} \mathrm{C}$ for $5 \mathrm{~min}, 37$ cycles of $94^{\circ} \mathrm{C}$ for $1 \mathrm{~min}$, $59^{\circ} \mathrm{C}$ for $1 \mathrm{~min}$ and $72^{\circ} \mathrm{C}$ for $1 \mathrm{~min}$, then $72^{\circ} \mathrm{C}$ for $10 \mathrm{~min}$. Enzymatic digestion was carried out in a $20-\mu \mathrm{L}$ volume containing $3 \mu \mathrm{L}$ of PCR product, 7.5 units of Bfal (New England Biolabs) and $2 \mu \mathrm{L}$ of $1 \times$ Nebbuffer 4 (New England Biolabs). This mix was then incubated at $37^{\circ} \mathrm{C}$ for 4 hours. The size and number of the different fragments were determined by electrophoretic migration on ethidium bromide-stained 3\% agarose gel. We expected to obtain one 188-bp fragment for the CC genotype, two fragments (162 and $26 \mathrm{bp})$ for the TT genotype, and three fragments (188, 162 and $26 \mathrm{bp})$ for the CT genotype.

The $+6762 \mathrm{C} / \mathrm{G},+6802 \mathrm{G} / \mathrm{A},+6926 \mathrm{C} / \mathrm{T}$ and $+7131 \mathrm{~T} / \mathrm{C}$ genotypes were determined by PCR followed by DNA sequencing. The forward and reverse primers were designed using Primer Express software (Applied Biosystems), as follows: 5'-GAGGCTGAGGGAAGGGACTC-3' and 5'-GGGTTTTTGGGTTTATCAGGAAC-3', producing a 590-bp fragment containing the four SNPs. The PGR mix and thermal cycling conditions were the same as described above for $-1306 \mathrm{C} / \mathrm{T}$. Sequencing was carried out in a $10-\mu \mathrm{L}$ volume containing 2 to $5 \mu \mathrm{L}$ of PCR product, $2 \mu \mathrm{L}$ of sequencing mix (Big Dye Terminator 3.1) and 10 pmol of forward and reverse primer. The thermal cycling conditions were $96^{\circ} \mathrm{C}$ for $2 \mathrm{~min}$, then 25 cycles of $96^{\circ} \mathrm{C}$ for $10 \mathrm{sec}, 55^{\circ} \mathrm{C}$ for $5 \mathrm{sec}$ and $60^{\circ} \mathrm{C}$ for $1 \mathrm{~min}$. Sequencing was performed by the Molecular Medicine Unit of Henri Mondor Hospital (IM3). Sequences were read in our laboratory with Chromas Pro 1.34 software.

Genotype analysis of $-129 \mathrm{G} / \mathrm{T},+256 \mathrm{~T} / \mathrm{C}, \mathrm{rs} 2664349 \mathrm{~A} / \mathrm{G}$ and rs2664352 $\mathrm{C} / \mathrm{T}$ was performed with allele-specific fluorogenic probes and the $\mathrm{TaqMan}^{\circledR}$ technique. Primers and probes were designed and synthesized by Applied Biosystems and provided as an SNP Genotyping Assay Mix specific for each SNP. Probes were labeled with the fluorophores, 6-carbofluorescein (FAM) or VIC (Table 1), and were minor groove binder (MGB) probes. PGR was carried out in a $20-\mu \mathrm{L}$ volume containing $10 \mathrm{ng}$ of genomic DNA, $10 \mu \mathrm{L}$ of TaqMan ${ }^{\circledR}$ Genotyping Master Mix (Applied Biosystems) and $1 \mu \mathrm{L}$ of TaqMan ${ }^{\circledR}$ SNP Genotyping Assay Mix $20 \times$ (Applied Biosystems). Thermal cycling conditions were $95^{\circ} \mathrm{C}$ for $10 \mathrm{~min}$, then 40 cycles of $92^{\circ} \mathrm{C}$ for $15 \mathrm{sec}$ and $60^{\circ} \mathrm{C}$ for $1 \mathrm{~min}$ in the ABI PRISM 7000 (Applied Biosystems). The genotypes were determined by reading the fluorescent signal of FAM and VIC from the end-products.

\section{Real-time quantitative PCR (qPCR)}

RNA from each sample extract was reverse-transcribed into cDNA by using $2 \mu \mathrm{g}$ of total RNA, Superscript II reverse transcriptase, and random hexamer primers (Invitrogen) according to the supplier's protocol. Realtime PCR was performed on an ABI Prism 7000 (Applied Biosystems, Courtaboeuf, France) using the following protocol: initial denaturation $\left(10 \mathrm{~min}\right.$ at $\left.95^{\circ} \mathrm{C}\right)$, then twostep amplification program $\left(15 \mathrm{~s}\right.$ at $95^{\circ} \mathrm{C}$ followed by $1 \mathrm{~min}$ at $\left.60^{\circ} \mathrm{C}\right)$ repeated 40 times. Melt curve analysis was used to check that a single specific amplified product was generated. Reaction mixtures consisted of $25 \mathrm{ng}$ cDNA, SYBR Green 2× PCR Master Mix 
(Applied Biosystems), and forward (5'-GAAGAAGCCTCGATGTGGTGTAC-3') and reverse primers (5'-CTTCTGCGCAGTTAATGCATAGC- $3^{\prime}$ ) in a reaction volume of $25 \mu$ l. Primers were designed using Primer Express software (Applied Biosystems). Realtime quantification was performed by measuring the increase in fluorescence caused by the binding of SYBR Green dye to doublestranded DNA at the end of each amplification cycle. Relative expression was determined by using the $\Delta \Delta \mathrm{Ct}$ (threshold cycle) method for normalized samples $(\Delta \mathrm{Ct})$ relative to a calibrator sample, according to the manufacturer's protocol. Each PCR run included a no-template control and a sample without reverse transcriptase. All measurements were performed in triplicate.

\section{Statistical analysis}

To test whether the genotypes were in Hardy-Weinberg equilibrium, we compared the observed genotype frequencies with their expected frequencies at equilibrium, based on the Chi2 test. Odds ratios (Ors) and $\mathrm{p}$ values adjusted for birth weight and ethnic origin, obtained by logistic regression, were calculated to test the association between the genotypes and BPD. Differences between treatment groups in animal studies were evaluated with the KruskalWallis non-parametric test for multiple group comparisons, and the Mann-Whitney U test for two-group comparisons.

\section{Results}

\section{Study population}

All infants were inborn, and received prophylactic surfactant in the delivery room. Of the 284 neonates initially enrolled, 21 died before 36 weeks PMA and were not included in the analysis.
Death was mainly due to severe neurological or infectious complications. Among survivors, 48\% had histologically defined chorioamnionitis, $8 \%$ had bacteriologically proven maternofetal infection, $76 \%$ received medical treatment for persistent ductus arteriosus, 16\% had bacteriologically proven postnatal sepsis, and only one had air leak. Ninety-two percent of mothers had received partial or complete steroid treatment before delivery. Forty-five $(17 \%)$ of the other 263 infants still needed oxygen supplementation at 36 weeks PMA and were thus diagnosed with BPD. As expected, the risk for BPD was significantly associated with birthweight, persistent ductus arteriosus, postnatal sepsis, and chorioamnionitis in univariate analysis (Table 2). Birthweight was the only significant risk factor for BPD in multivariate analysis $(\mathrm{OR}(95 \% \mathrm{CI})=0.996(0.993-0.998) ; \mathrm{p}=0.0017)$, and was therefore used as adjustment factor in genetic analysis.

\section{Genotyping}

The observed genotype frequencies did not deviate from HardyWeinberg equilibrium. The genotype distribution of 7 of the 9 studied SNPs was significantly influenced by ethnic origin. Table 3 shows the frequency of BPD in infants with different genotypes. After adjustment for birth weight and ethnic origin, the TT genotype of MMP16 C/T and the GG genotype of MMP16 A/G were found to be associated with a significantly lower risk of BPD (Table 3). The $\mathrm{T}$ allele frequency of the MMP16 C/T polymorphism was $50 \%$ in infants without DBP, as compared with only $34 \%$ in infants with BPD $(p=0.01)$. Similarly, the $G$ allele frequency of the MMP16 A/G polymorphism was found to be significantly higher in infants without BPD than in those with BPD: $37 \%$ versus $23 \%$, respectively $(\mathrm{p}<0.03)$. Twin cases did not

Table 2. Univariate analysis of perinatal factors potentially influencing the risk of BPD.

\begin{tabular}{|c|c|c|c|c|c|}
\hline Variable & & Infants with BPD/total (\%) & OR & $95 \% \mathrm{Cl}$ & $P$ \\
\hline \multirow[t]{2}{*}{ Sex } & Female & 20/132 (15) & 1 & & \\
\hline & Male & 25/131 (19) & 1.321 & $0.693-2.518$ & 0.398 \\
\hline \multirow[t]{4}{*}{ Ethnicity* } & European & 19/97 (20) & 1 & & \\
\hline & North Africa & $3 / 23(13)$ & 0.616 & $0.166-2.289$ & 0.469 \\
\hline & Sub-Saharan Africa & $15 / 103(15)$ & 0.700 & $0.333-1.470$ & 0.346 \\
\hline & Other & $8 / 40(20)$ & 1.026 & $0.408-2.583$ & 0.956 \\
\hline Birth weight (100 g) & & & 0.585 & $0.453-0.755$ & $<0.0001$ \\
\hline Gestational age (wk) & & & 0.804 & $0.590-1.096$ & 0.167 \\
\hline \multirow[t]{2}{*}{ Maternofetal infection } & No & $41 / 237(17)$ & 1 & & \\
\hline & Yes & $2 / 21(10)$ & 0.503 & $0.113-2.245$ & 0.368 \\
\hline Persistent ductus & No & $4 / 63(6)$ & 1 & & \\
\hline arteriosus§ & Yes & $39 / 195(20)$ & 3.687 & $1.263-10.770$ & 0.017 \\
\hline Surgical treatment for & No & $32 / 219(15)$ & 1 & & \\
\hline ductus arteriosus & Yes & $11 / 39(28)$ & 2.296 & $1.040-5.068$ & 0.040 \\
\hline \multirow[t]{2}{*}{ Chorioamnionitis } & No & $22 / 105(21)$ & 1 & & \\
\hline & Yes & 7/99 (7) & 0.287 & $0.117-0.707$ & 0.007 \\
\hline \multirow[t]{2}{*}{ Postnatal sepsis } & No & $32 / 218(15)$ & 1 & & \\
\hline & Yes & $12 / 41(29)$ & 2.405 & $1.113-5.196$ & 0.025 \\
\hline Antenatal steroid & No & $3 / 21(14)$ & 1 & & \\
\hline \multirow[t]{2}{*}{ therapy } & Partial & $16 / 76(21)$ & 1.600 & $0.419-6.117$ & 0.492 \\
\hline & Complete & 25/163 (15) & 1.087 & $0.298-3.966$ & 0.899 \\
\hline
\end{tabular}

"Ethnic group was based on the common origin of both parents; newborns whose parents had different ethnic origins were classified as "other" ;

${ }^{\S}$ Need for medical treatment

doi:10.1371/journal.pone.0003188.t002 
Table 3. SNP genotypes and frequency of BPD in infants; odds ratio and P values for the association between genotype and BPD, after adjustment for birth weight and ethnic origin, using logistic regression.

\begin{tabular}{|c|c|c|c|c|c|}
\hline Gene and position of SNP & Genotype & Infants with BPD/total (\%) & Adjusted OR & 95\% Cl & $\mathbf{P}$ \\
\hline MMP2 & CC & 30/162 (19) & - & & \\
\hline \multirow[t]{2}{*}{-1306} & CT & $11 / 44(25)$ & 1.123 & $0.446-2.828$ & 0.806 \\
\hline & $\pi$ & $0 / 4(0)$ & NC & & \\
\hline MMP14 & GG & $25 / 141(18)$ & & & \\
\hline \multirow[t]{2}{*}{-129} & GT & 12/82 (15) & 0.877 & $0.395-1.946$ & 0.747 \\
\hline & $\pi$ & $2 / 21(10)$ & 0.499 & $0.103-2.423$ & 0.388 \\
\hline MMP14 & $\pi$ & 30/179 (17) & - & & \\
\hline \multirow[t]{2}{*}{+256} & TC & 9/59 (15) & 0.667 & $0.280-1.587$ & 0.359 \\
\hline & CC & $0 / 7(0)$ & NC & & \\
\hline MMP14 & CC & 31/178 (17) & & & \\
\hline \multirow[t]{2}{*}{+6762} & CG & 9/67 (13) & 0.905 & $0.377-2.175$ & 0.823 \\
\hline & GG & $2 / 10(20)$ & 1.395 & $0.249-7.822$ & 0.705 \\
\hline MMP14 & GG & 34/203 (17) & & & \\
\hline \multirow[t]{2}{*}{+6802} & GA & $8 / 48(17)$ & 0.823 & $0.328-2.062$ & 0.678 \\
\hline & AA & $0 / 4(0)$ & NC & & \\
\hline MMP14 & CC & 29/163 (18) & & & \\
\hline \multirow[t]{2}{*}{+6926} & СT & 10/78 (13) & 0.684 & $0.290-1.613$ & 0.386 \\
\hline & $\pi$ & $3 / 14(21)$ & 1.109 & $0.268-4.579$ & 0.886 \\
\hline MMP14 & $\pi$ & 21/131 (16) & & & \\
\hline \multirow[t]{2}{*}{+7131} & TC & 17/96 (18) & 1.239 & $0.581-2.644$ & 0.579 \\
\hline & CC & $4 / 28(14)$ & 1.327 & $0.387-4.553$ & 0.653 \\
\hline MMP16 & AA & $25 / 113(22)$ & & & \\
\hline \multirow[t]{2}{*}{ +39811 } & AG & 16/100 (16) & 0.668 & $0.320-1.395$ & 0.282 \\
\hline & GG & 2/35 (6) & 0.208 & $0.044-0.978$ & 0.047 \\
\hline MMP16 & CC & 19/76 (25) & & & \\
\hline \multirow[t]{2}{*}{+43827} & СT & 19/112 (17) & 0.579 & $0.270-1.241$ & 0.160 \\
\hline & $\pi$ & $5 / 60(8)$ & 0.244 & $0.080-0.744$ & 0.013 \\
\hline
\end{tabular}

$\mathrm{NC}=$ not calculated

doi:10.1371/journal.pone.0003188.t003

significantly change results. Among survivors, 17 dizygotic twin pairs, 1 monozygotic twin pair, and 4 triplet pairs were present. Adjusted results for multiple births still identified TT and GG genotypes as significantly associated to a lower risk of BPD $(\mathrm{p}<0.02$ and $<0.05$, respectively).

Twenty-one infants died before 36 weeks of post-menstrual age. Among clinical factors significantly associated to the development of BPD in our population (Table 2), only birthweight $(747 \pm 36 \mathrm{~g}$ ) was found to significantly differ in deceaded infants from alive infants without BPD. None of SNPs were associated to death. When evaluating the composite outcome of death or BPD by 36 weeks of post-menstrual age, adjusted OR associated to GG and TT genotypes were $0.406(0.126-1.310 ; \mathrm{p}=0.1315)$ and $0.447(0.184-1.085 ; p=0.0753)$, respectively.

Power of our study results from the effect of SNP on disease (odds ratio), the sample size (n) and the type I error risk (alpha). When considering a multiplicative model for the allele associated with BPD, and the 45 children with BPD among 263 preterm infants recruited in this study, for alpha $=5 \%$, the power of the one-sided test to detect an association between BPD and an allele is equal to $99 \%$ with a $\mathrm{C}$ / $\mathrm{T}$ frequency of 0.50 and an odds ratio of 3.8 or is equal to $98 \%$ with a G/A frequency of 0.37 and an odds ratio of 3.3. If we take into account that the two SNPs found positively associated to BPD were tested among 9 candidates, group sample sizes of 45 and 218 achieve $82 \%$ power for each gene to detect a true allelic difference of at least 0.15 and with a false discovery rate of 0.05 .

\section{MMP2 level in tracheal aspirates}

The mean MMP2 protein content and activity did not differ significantly on day 0 between infants who subsequently developed BPD and those who did not (Table 4). However, second samples had significantly higher MMP2 contents and higher levels of activated MMP2 in BPD infants. The pattern of change in the activated MMP2 fraction differed significantly according to BPD status, with lower levels at birth in BDP infants, followed by a steep increase during the first days of life ( $p=0.0001$, repeated measures ANOVA). A significant association was found between polymorphisms in the MMP16 gene and the activated MMP2 fraction in second samples, but not in first samples (day 0) (Figure 1). No significant association was found between the MMP2 or MMP14 genotypes and MMP2 activity in tracheal aspirates (data not shown).

\section{MMP16 protein content in human samples}

Given this association between the MMP16 genotype and MMP2 activation, we used immunoblot to determine MMP16 protein content in supernatants of tracheal aspirates from infants 
Table 4. MMP2 ELISA values and zymographic analysis of MMP2 activity in tracheal effluents of premature newborns.

\begin{tabular}{llll}
\hline & & & \\
\hline & BPD - & BPD + & p \\
\hline Initial sample (HO) & $\mathrm{n}=126$ & $\mathrm{n}=22$ & \\
MMP2 content (ng.mL-1) & $1.36 \pm 0.06$ & $1.42 \pm 0.08$ & $\mathrm{NS}$ \\
Total activity (AU.mL-1) & $2.88 \pm 0.06$ & $3.03 \pm 0.09$ & $\mathrm{NS}$ \\
Activated form (AU.mL-1) & $1.96 \pm 0.07$ & $1.84 \pm 0.12$ & $\mathrm{NS}$ \\
Activated form (\% of total) & $19.7 \pm 1.5$ & $9.8 \pm 2.0$ & 0.009 \\
Second sample (day $\mathbf{1}$ to $\mathbf{3})$ & $\mathrm{n}=89$ & $\mathrm{n}=16$ & \\
MMP2 content (ng.mL-1) & $1.29 \pm 0.04$ & $1.51 \pm 0.09$ & 0.034 \\
Total activity (AU.mL-1) & $2.72 \pm 0.06$ & $3.00 \pm 0.08$ & 0.054 \\
Activated form (AU.mL-1) & $1.82 \pm 0.07$ & $2.29 \pm 0.09$ & 0.009 \\
Activated form (\% of total) & $19.0 \pm 1.6$ & $26.0 \pm 4.3$ & NS \\
\hline
\end{tabular}

Infants were ascribed to one of two subgroups according to their BPD phenotype. Values are means \pm SEM and were log transformed to respect a normal distribution.

doi:10.1371/journal.pone.0003188.t004

with homogenous genotypes, namely GG and TT (n=8) or GC and $\mathrm{AA}(\mathrm{n}=9)$. A single $45-\mathrm{kD}$ band was observed in every case. Tracheal aspirates from infants with the GG-TT genotype contained three times less MMP16 protein than those from infants with the CC-AA genotype (Figure 2).

MMP16 protein expression was also determined in lung tissue from eight deceased fetuses without lung disease, sampled between 13 and 35 weeks of pregnancy (Figure 3A). Three bands were observed, at $65 \mathrm{kD}, 45 \mathrm{kD}$, and $\sim 35 \mathrm{kD}$. While expression of the $65-\mathrm{kD}$ band remained stable during fetal life, expression of the lower-molecularweight species rose sharply from the 30th week of pregnancy.

\section{MMP16 expression in rat lung}

Expression profile of MMP16 mRNA and protein from fetal life to adulthood. The MMP16 mRNA level was evaluated in developing rat lung from fetal day 18 (canalicular stage) to adulthood. Gene expression changed little until postnatal day 1, then increased gradually to about five times the fetal level on day 14 ,
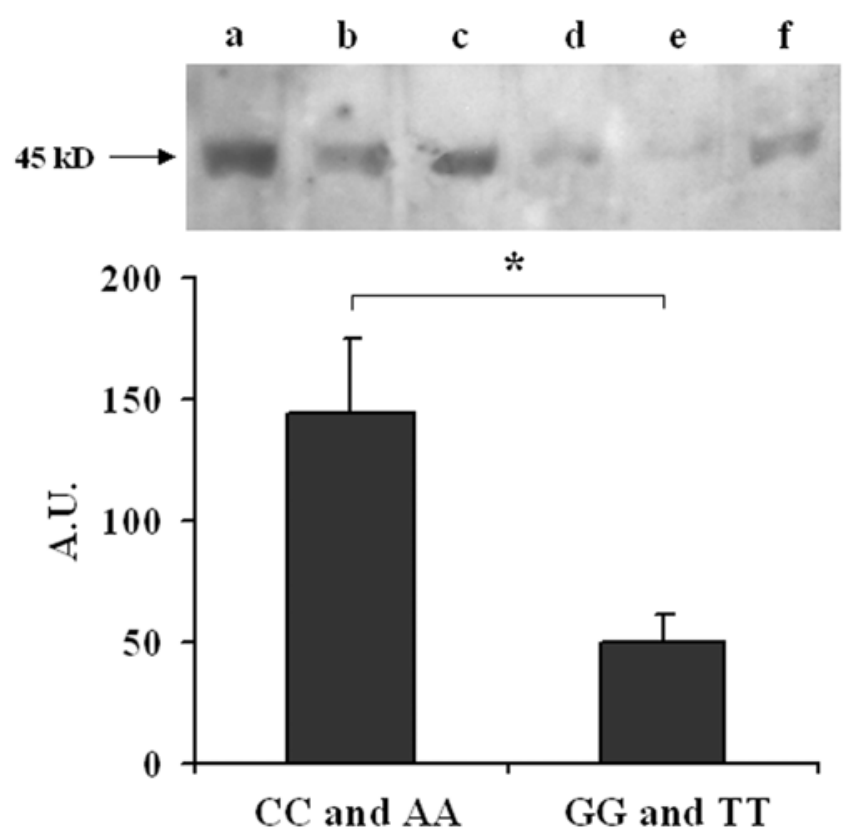

Figure 2. MMP16 immunoblots of tracheal aspirate supernatants from infants with the MMP16 AA-CC (lanes a-c) and GGTT (lanes d-f) genotypes. Upper: a $45-\mathrm{kDa}$ band was clearly identified in AA-CC infants but was barely visible in GG-TT infants. Lower: densitometric analysis (arbitrary units [A.U.]) in 9 AA-CC infants and $8 \mathrm{GG}-\mathrm{TT}$ infants, showing a significant difference in the MMP16 level (Mann Whitney $\mathrm{p}<0.02$ ).

doi:10.1371/journal.pone.0003188.g002

remained elevated until day 24, and returned to an extremely low level (lower than before birth) in adulthood (Figure 3B). As in human tissue, immunoblotting showed three bands, with molecular weights of $65 \mathrm{kD}, 45 \mathrm{kD}$, and $\sim 35 \mathrm{kD}$. Expression of all the bands increased from postnatal day 5 to postnatal day 21 , but the strongest increase was observed for the $65 \mathrm{kD}$ band (Figure 3C). Confirmatory experiments were performed with quantification of protein expression in 4 individual samples at days 1, 7, and 21. A significant increase was found for the $65 \mathrm{kD}$ protein (Table 5). The
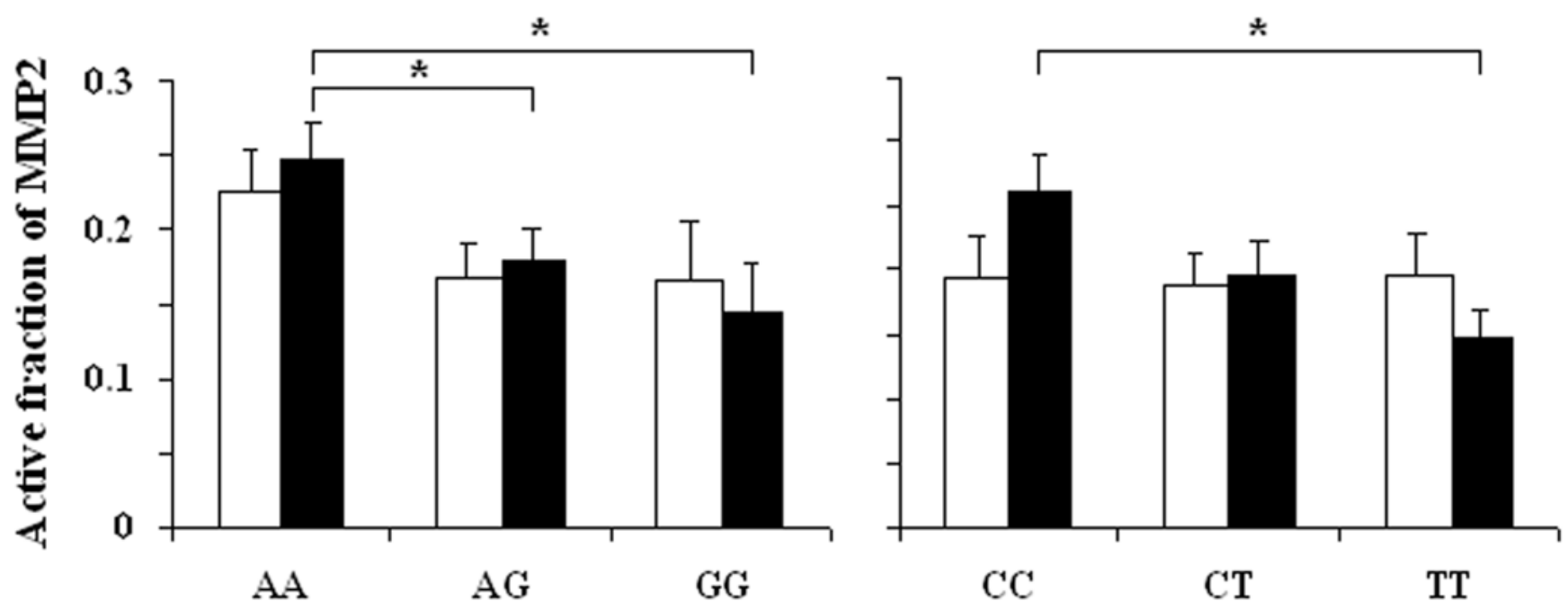

Figure 1. Association between MMP16 polymorphisms (A: rs2664349 A/G; B: rs2664352 C/T) and the size of the activated fraction of MMP2 measured in tracheal aspirates. Aspirates were collected immediately after birth (open bars), and between 1 and 3 days of life (closed bars). ${ }^{*} \mathrm{p}<0.05$ in post-hoc analysis.

doi:10.1371/journal.pone.0003188.g001 


\section{A - Human (protein)}

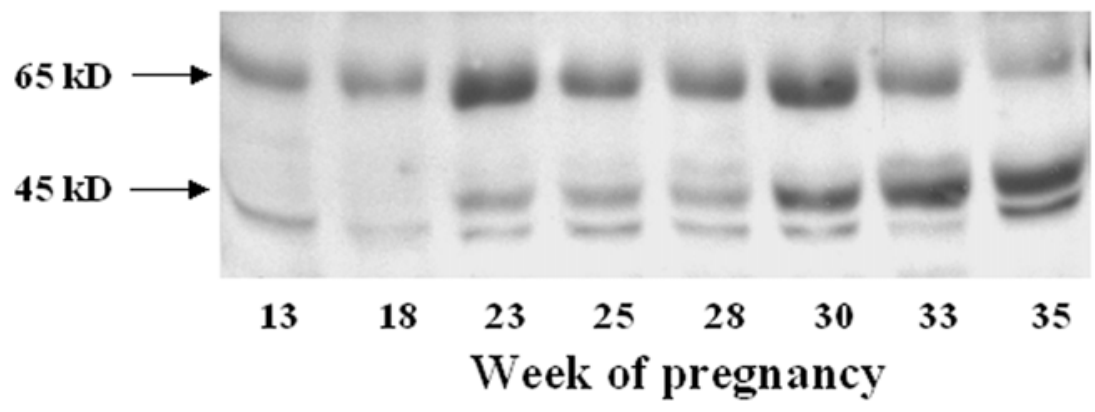

\section{B - Rat (mRNA)}

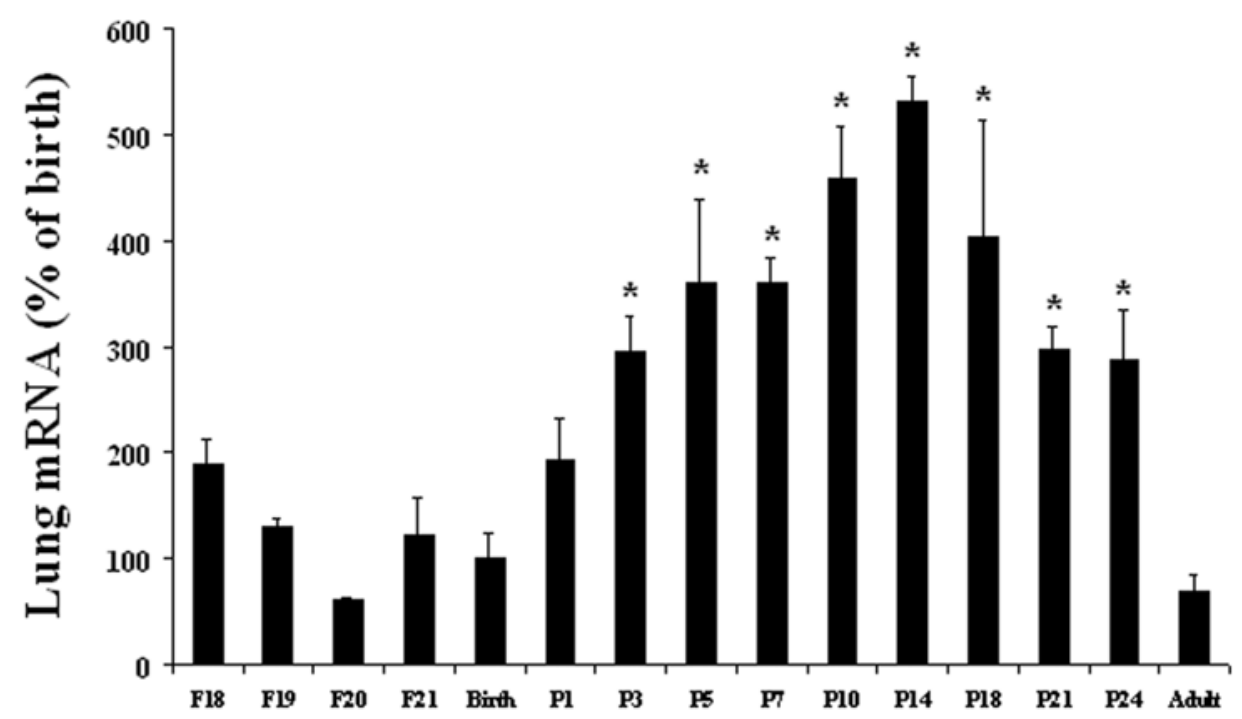

\section{C - Rat (protein)}

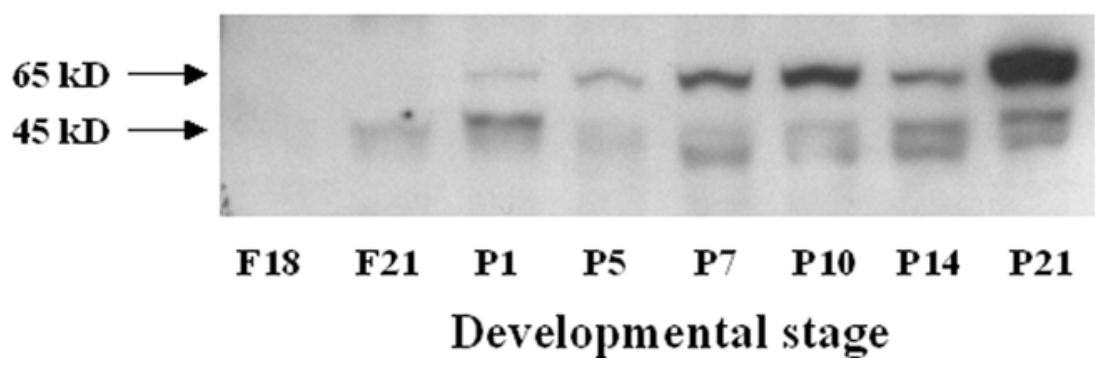

Figure 3. Developmental pattern of MMP16 gene and protein expression in control lungs. A. Immunoblot of lung homogenates from human fetuses without lung disease, at 11 to 36 weeks of gestation. B. Changes in the MMP16 mRNA expression level in rat whole lung tissue. Expression was quantified by real-time PCR from fetal life (canalicular stage of development) to adulthood, in 3 to 5 individual lung samples per stage. The birth level was arbitrarily given a value of 100 . Values are means \pm SEM. ${ }^{*} p<0.05$ versus birth level. C. Immunoblot of lung homogenates from control rats, from fetal life to adulthood. doi:10.1371/journal.pone.0003188.g003

$45 \mathrm{kD}$ form increased slightly from day 1 to day 21 , but the difference was not significant.

Effects of hyperoxia and dexamethasone on MMP16 gene expression in postnatal rat lung. In newborn rats exposed to hyperoxia for 7 days, the MMP16 gene expression level (Figure 4A) was about $60 \%$ lower than in controls. Similarly, dexamethasone caused a dose-dependent fall in the MMP16 mRNA level. MMP16 gene expression fell by $30 \%$ and $>50 \%$, respectively, with the 0.1 and $0.5 \mu \mathrm{g} / \mathrm{kg} / \mathrm{d}$ dexamethasone dosages (Figure 4B). Protein changes, evaluated by immunoblotting, were concordant with 
Table 5. Densitometric analysis (arbitrary units \pm SEM) of immunoblots of lung homogenates from control rats at three postnatal ages: day 1 , day 7 , and day 21 ( $n=4$ at each stage).

\begin{tabular}{llll}
\hline & & & \\
\hline & Day $\mathbf{1}$ & Day $\mathbf{7}$ & Day 21 \\
\hline $65 \mathrm{kD}$ & $726 \pm 223$ & $1277 \pm 314$ & $2308 \pm 385^{*}$ \\
$45 \mathrm{kD}$ & $1374 \pm 282$ & $757 \pm 193$ & $1802 \pm 83$ \\
\hline
\end{tabular}

Ponceau S stain was used as loader control. Normalization of immunoblots was achieved through the run of a common sample. ${ }^{*} \mathrm{p}<0.05$ as compared with day 1 .

doi:10.1371/journal.pone.0003188.t005

RNA changes. Densitometry results, expressed as a percentage of the control value, showed that the $65 \mathrm{kD}$ form decreased to $28 \pm 5 \%$ $(\mathrm{n}=4 ; \mathrm{p}<0.03)$ and to $48 \pm 8 \%(\mathrm{n}=4 ; \mathrm{p}<0.03)$, after hyperoxia or $0.5 \mu \mathrm{g} / \mathrm{kg} / \mathrm{d}$ dexamethasone, respectively. The changes in the 45 $\mathrm{kD}$ form $(48 \pm 15 \%$, and $176 \pm 32 \%$ of control values, respectively) were not found to be significant.

\section{Discussion}

Genetic susceptibility to BPD was demonstrated in a recent study of monozygotic and dizygotic twins [12]. After controlling for covariates, genetic factors were shown to account for $53 \%$ of the variance in the risk of BPD [12]. Genes encoding multifunctional proteins in the distal lung are prime candidates for determining susceptibility to BPD.

We sought links between BPD and SNPs in three MMP genes. We found a significant association between two SNPs in the MMP16 gene and BPD outcome, even after adjustment for birth weight and ethnic origin. The MMP16 genotype also influenced the size of the activated MMP2 fraction in the infants' tracheal aspirates. In addition, MMP16 gene expression was high during normal newborn rat lung alveolarization, and was markedly reduced by insults that arrested alveolarization.

Heterogeneous management of preterm infants hampers genetic analyses. Indeed, the frequency of BPD varies widely among neonatal intensive care units, underlining the role of environmental factors. The prospective nature of our study helped to ensure that newborns who did and did not subsequently develop BPD received similar initial management. The rate of BPD was low $(17 \%)$, reflecting good control of external insults. Furthermore, oxygen dependency at a postmenstrual age of 36 weeks was diagnosed with a validated test [15].

No association was found between the risk of BPD and SNPs in the MMP2 or MMP14 gene. The SNPs we selected have previously been linked to human respiratory diseases, including COPD [14], and lung cancer $[19,20]$. The proteinases produced by these two genes play an important role in the control of distal lung development [4,7-9]. MMP2 has also been implicated in the pathogenesis of BPD [5,6]. In the present study, MMP2 content and activity were measured in tracheal effluents. The main finding was the association between the risk of BPD and the proportion of the activated fraction of MMP2. Relative to infants who did not develop BPD, infants who developed BPD had a significantly smaller fraction of active MMP2 at birth, but a larger fraction at the second sampling time. These results support our previous findings [5]. They are also in keeping with the early increase in the active MMP2 fraction previously observed in the lungs of newborn rats exposed to hyperoxia [21]. However, contrary to our previous findings, total MMP2 activity did not differ on day 0 between neonates who subsequently developed BPD and those who did not in this study.
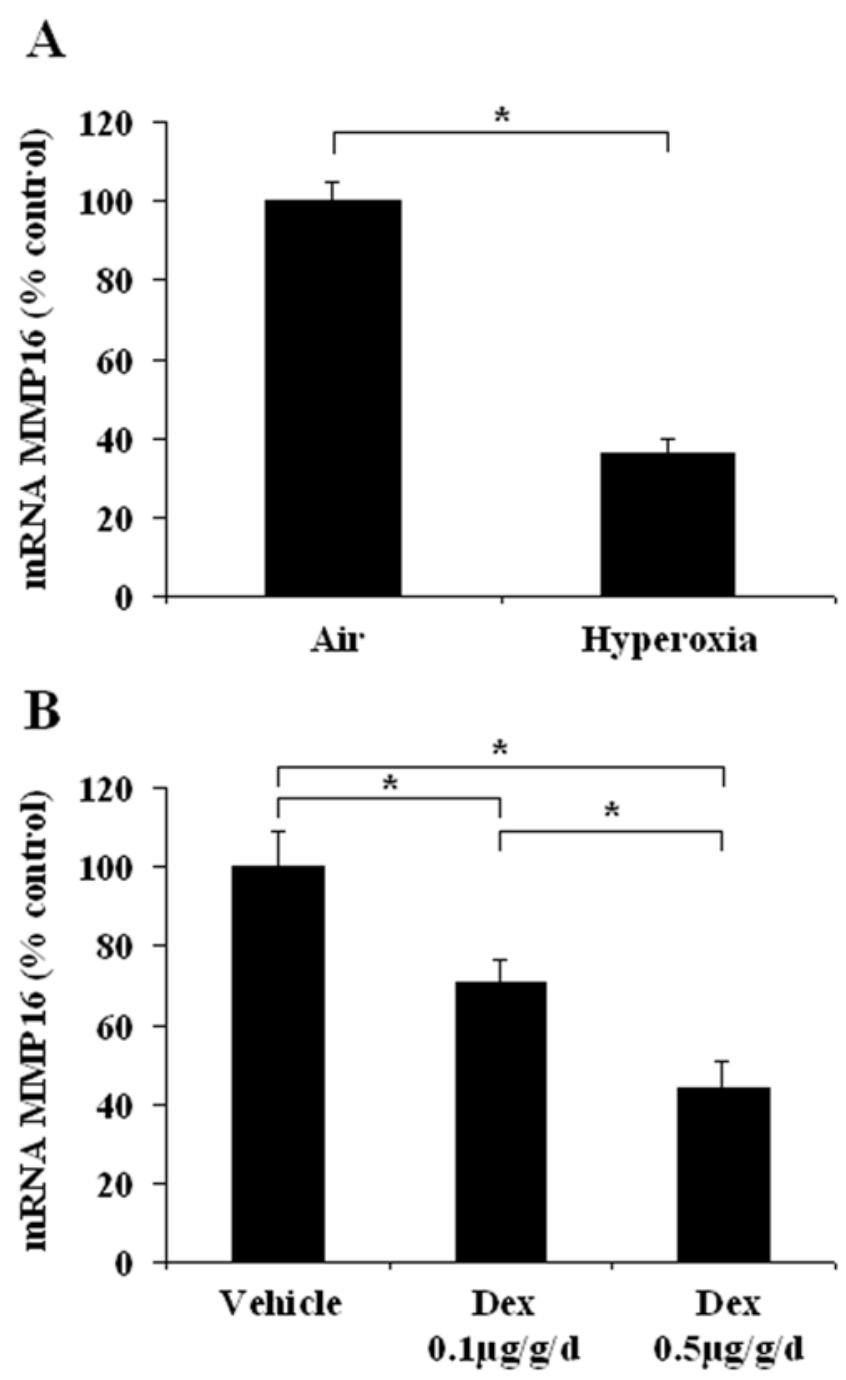

Figure 4. Changes in lung MMP16 mRNA expression in newborn rats exposed to insults associated with alveolar developmental arrest. A: Exposure to hyperoxia $\left(\mathrm{O}_{2}>95 \%\right)$ from birth to day 6; B: Daily administration of dexamethasone from birth to day 5 (two doses). Results are expressed as a percentage of the control value. ${ }^{*} p<0.05$ in two-group comparisons.

doi:10.1371/journal.pone.0003188.g004

Differences in the study populations might account for this apparent discrepancy. In the present study the neonates were more premature, were all sampled within minutes after birth, and all received prophylactic surfactant administration. No association was found between the MMP2 and MMP14 genotypes and MMP2 levels in tracheal aspirates. By contrast, the MMP16 genotype was associated both with the risk of BPD and with the level of MMP2 activity in tracheal aspirates. In keeping with our observation that BPD was associated with an elevated active fraction of MMP2, the MMP16 genotypes associated with a lower risk of BPD, i.e. GG and TT, were also associated with lower active fractions of MMP2.

MMP16, also called MT3-MMP, is very similar to MMP14 in both structure and function. It is present in membranes as an active $65-\mathrm{kD}$ form, and has recently been shown to be shed in a 32- to $35-\mathrm{kD}$ soluble form that retains its ability to activate MMP2 [22]. A 45-kD soluble form of MMP16 has also been suggested to be formed by alternative splicing of mRNA [11], the splicing point potentially lying in the hemopexin-like domain. It was recently suggested that the two forms of this protein could play distinct 
roles during embryogenesis. Indeed, Xenopus laevis embryos injected with full-length MMP16 mRNA showed no significant changes in the expression levels of the tissue-specific genes encoding endodermin, chordin and muscle actin, whereas mRNA for the soluble form of MMP16 reduced the expression of all three marker genes. In addition, while full-length tethered MMP16 failed to alter gelatinase activity, a $50 \%$ increase occurred after injection of the soluble form [23]. MMP16 was recently shown to act as a major collagenolytic enzyme in bone and cartilage during mammalian embryogenesis, with MMP16-deficient mice displaying delayed skeletal growth [24]. Although no genotype-related abnormality is reported in lungs of adult mutant mice in the international database resource for the laboratory mouse (http:// www.informatics.jax.org/external/ko/deltagen/1241.html), lung development was not extensively studied in these mice. MMP16 is known to be expressed in the human lung [10]. Its role is largely obscure, but it has been implicated in disease processes such as idiopathic pulmonary fibrosis [25]. Our study is therefore the first to provide strong evidence of MMP16 participation in normal and abnormal lung development, in both newborn rats and premature infants. In newborn rats, lung MMP16 gene expression is low during the canalicular and saccular stages, and increases significantly very close to the beginning of alveolarization, i.e. postnatal day 4 [26]. Then, lung MMP16 gene expression peaks on day 14 and remains elevated until day 24 of life, before falling to very low levels in adulthood. MMP16 protein expression in rat lung ran parallel to MMP16 gene expression, with a gradual increase in both the presumed transmembrane and soluble forms during alveolarization, and strong expression on day 21. The results we obtained with homogenates of normal human fetus lungs sampled at various stages were concordant with the results we obtained in rats. We observed a clear increase in the expression of the presumed soluble form as early as 30 weeks of human pregnancy, i.e. just before the beginning of alveolarization [26]. Although these observations were gained from tissues collected postmortem, these samples have previously been proven suitable for evidencing developmental changes as well as differences between normal and diseased lungs [17,27]. We found that the pulmonary MMP16 expression profile differed from that of MMP14 in lung fibroblasts from newborn rats. MMP14 gene expression increased at the time of peak alveolarization but rapidly returned to the basal level as early as 16 days of life [7]. Although MMP16 is closely related to MMP14 in terms of its molecular structure and tissue expression pattern $[10,24]$, differences in the expression profiles suggest that MMP16 is not merely functionally redundant to MMP14. Alveolarization takes place between days 4 and 21 in rats and comprises two successive steps, namely secondary alveolar septation from day 4 to day 14 , and alveolar wall thinning with fusion of the initially double capillary layer into a single, central microvascular network from day 14 to 21 [26]. The different expression profiles of MMP14 and MMP16 suggest primary involvement of the former in the first step and of the latter in the whole process, including the second step.

The functional domains of MMP16 and MMP14 are not interchangeable for pro-MMP2 activation and collagenolysis, despite their similarities [28]. It was also shown recently that the collagenolytic activity of MMP16 is complementary to that of MMP14 in mice lacking both enzymes [24]. Further evidence

\section{References}

1. Fanaroff AA, Stoll BJ, Wright LL, Carlo WA, Ehrenkranz RA, et al. (2007) Trends in neonatal morbidity and mortality for very low birthweight infants. Am J Obstet Gynecol 196: 147 e141-148.

2. Jobe AH, Bancalari E (2001) Bronchopulmonary dysplasia. Am J Respir Crit Care Med 163: 1723-1729. supporting the role of MMP16 as a significant controller of alveolar growth/maturation comes from its down-regulation in models of arrested of lung development. We found that hyperoxia and dexamethasone, both of which impair alveolarization, strongly reduced lung MMP16 gene expression in newborn rats. We also observed a significant association between two polymorphisms in the MMP16 gene and the risk of BPD in highly premature infants. Despite strong evidence of genetic susceptibility to BPD [12], only polymorphisms in the genes for glutathione-S-transferase-P1 [29], surfactant protein-B [30], and TNF-a [31] have been identified as possible genetic determinants. The functionality of the two SNPs that we studied in the MMP16 gene remains to be determined. They were chosen because they are tags for a haplotype in a gene region that codes for the hemopexin-like domain and that might be alternatively spliced [11]. The association we found between the infants' genotypes and both the MMP16 protein level and the size of the activated MMP2 fraction in tracheal aspirates strongly suggests that these polymorphisms have functional consequences, although no definitive proof is given that the changes in MMP16 are causative of reduced MMP2 activation.. The premature infants had a gestational age lower than 28 weeks, corresponding to the early saccular stage of lung development. We found that expression of the $45-\mathrm{kD}$ soluble form of MM16 was low in human fetal lung tissue. The TT and GG genotypes were associated with a 3-fold lower 45-kD MMP16 protein content in tracheal aspirates collected within 3 days after birth, and with a smaller MMP2 active fraction, in keeping with experimental results linking expression of the soluble MMP16 form to the level of gelatinase activity [23]. These genotypes were also found to be associated with a significantly lower risk of BPD, suggesting that maintenance of the physiologically low expression of the $45-\mathrm{kD}$ soluble MMP16 isoform at this stage of lung development protects against BPD. Apparent discrepancies between changes in MMP16 expression in BPD infants and changes in animal models of arrested alveolarization may be due to differences in time frame. Animal experiments are models of arrested alveolar septation, a stage associated to a strong physiological increase in MMP16 expression. Thus, in both BPD infants and animal models, altered distal lung development is associated to opposite changes in MMP16 expression as those normally observed in the corresponding lung development stage. It is also noteworthy that changes in protein expression in animal models were found significant only for the tissular $65 \mathrm{kD}$ form. For evident reasons, we were not able to evaluate this tissular form in human prematures. Changes in balance between tissular and soluble forms may also contribute to lung growth disorders.

In conclusion, we identify MMP16 as a possible new regulator of lung alveolar development and provide evidence that MMP16 polymorphisms are associated with protection from bronchopulmonary dysplasia in highly premature infants.

\section{Author Contributions}

Conceived and designed the experiments: AH JRB CD. Performed the experiments: AH MLFM IH OB EM. Analyzed the data: AH FD MLFM IH PHJ OB SA JRB CD CD. Contributed reagents/materials/analysis tools: FD PHJ EM AB JRB CD CD. Wrote the paper: AH JRB CD. Important role in collection of clinical data: FD CD. Important role in collection of DNA: CD.

3. Greenlee KJ, Werb Z, Kheradmand F (2007) Matrix metalloproteinases in lung: multiple, multifarious, and multifaceted. Physiol Rev 87: 69-98.

4. Kheradmand F, Rishi K, Werb Z (2002) Signaling through the EGF receptor controls lung morphogenesis in part by regulating MT1-MMP-mediated activation of gelatinase A/MMP2. J Cell Sci 115: 839-848. 
5. Danan C, Jarreau PH, Franco ML, Dassieu G, Grillon C, et al. (2002) Gelatinase activities in the airways of premature infants and development of bronchopulmonary dysplasia. Am J Physiol (Lung Cell Mol Biol) 283: L1086-1093.

6. Schulz GG, Sawicki G, Lemke RP, Roeten BM, Schulz R, et al. (2004) MMP-2 and MMP-9 and their tissue inhibitors in the plasma of preterm and term neonates. Pediatr Res 55: 794-801.

7. Boucherat O, Bourbon JR, Barlier-Mur AM, Chailley-Heu B, D’Ortho MP, et al. (2007) Differential expression of matrix metalloproteinases and inhibitors in developing rat lung mesenchymal and epithelial cells. Pediatr Res 62: 20-25.

8. Atkinson JJ, Holmbeck K, Yamada S, Birkedal-Hansen H, Parks WC, et al. (2005) Membrane-type 1 matrix metalloproteinase is required for normal alveolar development. Dev Dyn 232: 1079-1090.

9. Oblander SA, Zhou Z, Galvez BG, Starcher B, Shannon JM, et al. (2005) Distinctive functions of membrane type 1 matrix-metalloprotease (MT1-MMP or MMP-14) in lung and submandibular gland development are independent of its role in pro-MMP-2 activation. Dev Biol 277: 255-269.

10. Takino T, Sato H, Shinagawa A, Seiki M (1995) Identification of the second membrane-type matrix metalloproteinase (MT-MMP-2) gene from a human placenta cDNA library. MT-MMPs form a unique membrane-type subclass in the MMP family. J Biol Chem 270: 23013-23020.

11. Matsumoto S, Katoh M, Saito S, Watanabe T, Masuho Y (1997) Identification of soluble type of membrane-type matrix metalloproteinase- 3 formed by alternatively spliced mRNA. Biochim Biophys Acta 1354: 159-170.

12. Bhandari V, Bizzarro MJ, Shetty A, Zhong X, Page GP, et al. (2006) Familial and genetic susceptibility to major neonatal morbidities in preterm twins. Pediatrics 117: 1901-1906.

13. Price SJ, Greaves DR, Watkins H (2001) Identification of novel, functional genetic variants in the human matrix metalloproteinase-2 gene: role of $\mathrm{Spl}$ in allele-specific transcriptional regulation. J Biol Chem 276: 7549-7558.

14. Saitoh W, Sakamoto T, Hegab AE, Nomura A, Ishii Y, et al. (2006) MMP14 gene polymorphisms in chronic obstructive pulmonary disease. Int J Mol Med 17: 621-626.

15. Walsh MC, Yao Q, Gettner P, Hale E, Collins M, et al. (2004) Impact of a physiologic definition on bronchopulmonary dysplasia rates. Pediatrics 114: 1305-1311.

16. Danan C, Franco M, Jarreau P, Dassieu G, Chailley-Heu B, et al. (2002) High levels of keratinocyte growth factor in airways of premature infants predicted absence of bronchopulmonary dysplasia. Am J Respir Crit Care Med 165: 1384-1387.

17. Boucherat O, Benachi A, Chailley-Heu B, Franco-Montoya ML, Elie C, et al. (2007) Surfactant maturation is not delayed in human fetuses with diaphragmatic hernia. PLoS Med 4: e237.
18. Boucherat O, Franco-Montoya ML, Thibault C, Incitti R, Chailley-Heu B, et al. (2007) Gene expression profiling in lung fibroblasts reveals new players in alveolarization. Physiol Genomics 32: 128-141.

19. Yu C, Pan K, Xing D, Liang G, Tan W, et al. (2002) Correlation between a single nucleotide polymorphism in the matrix metalloproteinase-2 promoter and risk of lung cancer. Cancer Res 62: 6430-6433.

20. Zhou Y, Yu C, Miao X, Wang Y, Tan W, et al. (2005) Functional haplotypes in the promoter of matrix metalloproteinase-2 and lung cancer susceptibility. Carcinogenesis 26: 1117-1121.

21. Buckley S, Warburton D (2002) Dynamics of metalloproteinase-2 and -9, TGFbeta, and uPA activities during normoxic vs. hyperoxic alveolarization. Am J Physiol Lung Cell Mol Physiol 283: L747-754.

22. Zhao H, Bernardo MM, Osenkowski P, Sohail A, Pei D, et al. (2004) Differential inhibition of membrane type 3 (MT3)-matrix metalloproteinase (MMP) and MT1-MMP by tissue inhibitor of metalloproteinase (TIMP)-2 and TIMP-3 rgulates pro-MMP-2 activation. J Biol Chem 279: 8592-8601.

23. Walsh LA, Cooper CA, Damjanovski S (2007) Soluble membrane-type 3 matrix metalloprioteinase causes changes in gene expression and increased gelatinase activity during Xenopus laevis development. Int J Dev Biol 51: 389-395.

24. Shi J, Son MY, Yamada S, Szabova L, Kahan S, et al. (2008) Membrane-type MMPs enable extracellular matrix permissiveness and mesenchymal cell proliferation during embryogenesis. Dev Biol 313: 196-209.

25. Garcia-Alvarez J, Ramirez R, Sampieri CL, Nuttall RK, Edwards DR, et al. (2006) Membrane type-matrix metalloproteinases in idiopathic pulmonary fibrosis. Sarcoidosis Vasc Diffuse Lung Dis 23: 13-21.

26. Burri PH (1984) Fetal and postnatal development of the lung. Annu Rev Physiol 46: 617-628.

27. Boucherat O, Benachi A, Barlier-Mur AM, Franco-Montoya ML, Martinovic J, et al. (2007) Decreased lung fibroblast growth factor 18 and elastin in human congenital diaphragmatic hernia and animal models. Am J Respir Crit Care Med 175: 1066-1077.

28. Jiang A, Pei D (2003) Distinct roles of catalytic and pexin-like domains in membrane-type matrix metalloproteinase (MMP)-mediated pro-MMP-2 activation and collagenolysis. J Biol Chem 278: 38765-38771.

29. Manar MH, Brown MR, Gauthier TW, Brown LA (2004) Association of glutathione-S-transferase-P1 (GST-P1) polymorphisms with bronchopulmonary dysplasia. J Perinatol 24: 30-35.

30. Rova M, Haataja R, Marttila R, Ollikainen V, Tammela O, et al. (2004) Data mining and multiparameter analysis of lung surfactant protein genes in bronchopulmonary dysplasia. Hum Mol Genet 13: 1095-1104.

31. Kazzi SN, Kim UO, Quasney MW, Buhimschi I (2004) Polymorphism of tumor necrosis factor-alpha and risk and severity of bronchopulmonary dysplasia among very low birth weight infants. Pediatrics 114: e243-248. 